\title{
Ex vitro acclimatization of plantain plantlets micropropagated in temporary immersion bioreactor
}

\author{
C. ARAGÓN ${ }^{1,2}$, L. CARVALHO ${ }^{1}$, J. GONZÁLEZ ${ }^{2}$, M. ESCALONA $^{2}$ and S. AMÂNCIO ${ }^{1 *}$ \\ Departamento de Botânica e Engenharia Biologica, Instituto Superior de Agronomia, \\ Universidade Técnica de Lisboa, 1349-017 Lisboa, Portugal ${ }^{1}$ \\ Laboratorio de Células y Cultivo Tejidos, Centro de Bioplantas, Universidad de Ciego de Ávila, \\ Ciego de Ávila, Cuba ${ }^{2}$
}

\begin{abstract}
Plantain (Musa ABB CEMSA 3/4) plantlets were micropropagated in temporary immersion bioreactors (TIB) or in gelled medium (GM). After ex vitro transfer ROS accumulation was determined by infiltrating leaves with nitroblue tetrazolium (NBT) and 3,3'-diaminobenzidine (DAB). Stomatal cells were more stained with NBT and DAB in GM plants than in TIB plants, but the difference disappeared at the end of acclimatization. At the end of the in vitro phase, GM plantlets showed higher activities of ascorbate peroxidase (APX), dehydroascorbate reductase (DHAR), monodehydroascorbate reductase (MDHAR) and glutathione reductase (GR), while activities of catalase (CAT), superoxide dismutase (SOD) and glutathione transferase (GT) were higher in TIB grown plantlets. At the end of acclimatization GT, SOD, CAT and MDHAR stabilized at low values of activity in plantlets derived from both treatments. Concerning the correspondent genes, GM plantlets showed higher expression of all transcripts with the exception of $C u Z n S O D$. The immunobloting of peroxiredoxins (PRXs) showed that chloroplast-located PRXs were expressed at higher levels in TIB plantlets, some showing polymerization. In conclusion, TIB grown plantlets had an improved anti-oxidative response when compared with GM.
\end{abstract}

Additional key words: ascorbate-glutathione cycle, ex vitro growth, oxidative stress, TIB culture.

\section{Introduction}

The commercial application of micropropagation for a broader range of species would only take place if new technologies were available to automate certain procedures and if acclimatization protocols were improved (Kitto 1997). The use of temporary immersion bioreactors (TIB) has proven to be an alternative to standard gelled medium (GM). TIB is an efficient propagation technique, that improves plantlet morphology and physiology and it represents a low cost option for the massive production of plantlets for the tropical agricultural industry (e.g. sugarcane, plantain, pineapple) (Lorenzo et al. 2001, Escalona et al. 2003, Aragón et al. 2005).

Evidence of oxidative stress during micropropagation has often been reported (Van Huylenbroeck et al. 2000, Carvalho et al. 2001). Photosynthesis can be down

regulated either due to a lack of $\mathrm{CO}_{2}$ or ethylene production in closed vessels or due to the feedback inhibition of Calvin cycle enzymes by the sucrose in the medium (Jackson et al. 1991, Tanaka et al. 2005). Moreover, the transition of the plantlets to an ex vitro conditions under high irradiance can lead to the production of reactive oxygen species (ROS; for review see Bat'ková et al. 2008). However, comparisons of GM with TIB have so far focused only on carbon metabolism (e.g. Aragon et al. 2005).

The aim of this paper is to show the differences in response to oxidative stress during acclimatization in plantain plantlets propagated on GM or in TIB by monitoring ROS accumulation, the activities of antioxidative enzymes and expression of corresponding genes.

Received 5 July 2008, accepted 25 March 2009.

Abbreviations: APX - ascorbate peroxidase (EC 1.11.1.11); BA - 6-benzylaminopurine; CAT - catalase (EC 1.11.1.6); DAB - 3,3'diaminobenzidine; DHAR - dehydroascorbate reductase (EC 1.8.5.1); GM - gelled medium; GR - glutathione reductase (EC 1.6.4.2); GT - glutathione transferase (EC 2.5.1.18); MDHAR - monodehydroascorbate reductase (EC 1.6.5.4); MS - Murashige and Skoog medium; NBT - nitroblue tetrazolium; PPFD - photosynthetic photon flux density; PRX - peroxiredoxin; ROS - reactive oxygen species; SOD - superoxide dismutase (EC 1.15.1.1); TIB - temporary immersion bioreactor.

Acknowledgements: To the program Alban, scholarship number E06D100217CU (C.A), to "Fundação para a Ciência e Tecnologia", co-financed by FEDER for post-doc grant SFRH/BPD/5707/2001 (L.C.) and "Plurianual" funds to CBAA.

* Corresponding author: fax: (+351) 21 3653238, e-mail: samport@isa.utl.pt 


\section{Materials and methods}

Plants: Plantain plantlets (Musa AAB, CEMSA 3/4) were subjected to three sub-culture cycles of $21 \mathrm{~d}$ each, in culture media containing Murashige and Skoog (1962) salts and vitamins, supplemented with $30 \mathrm{~g} \mathrm{dm}^{-3}$ sucrose $(\mathrm{m} / \mathrm{v})$ and $1.33 \mu \mathrm{M}$ 6-benzylaminopurine (BA). Two different techniques, GM (gelled medium) and TIB (temporary immersion bioreactors) were applied for the last subculture $(21 \mathrm{~d})$. In both techniques, the media used consisted of MS salts and vitamins supplemented with $30 \mathrm{~g} \mathrm{dm}^{-3}$ sucrose and without plant growth regulators. In GM, plantlets were placed in Magenta vessels (SigmaAldrich, St. Louis, MO, USA) containing $50 \mathrm{~cm}^{3}$ of media gelled with $2.0 \mathrm{~g} \mathrm{dm}^{-3}$ Gelrite $(5$ shoots per vessel). TIB was performed in containers (Schott, Mainz, Germany) with $200 \mathrm{~cm}^{3}$ of media and 5 shoots per bioreactor (Escalona et al. 2003). Shoots were immersed for $4 \mathrm{~min}$ every $3 \mathrm{~h}$. Photosynthetic photon flux density (PPFD) was $45 \pm 5 \mu \mathrm{mol} \mathrm{m} \mathrm{m}^{-2} \mathrm{~s}^{-1}$ and the photoperiod was $16 \mathrm{~h}$ in both propagation techniques.

Microcuttings produced under TIB and GM were transplanted to pots containing a sterilised mixture of moistened peat and Perlite $(1: 1, \mathrm{v} / \mathrm{v})$ and placed in glass chambers (500E, Aralab, Porto Salvo, Portugal). PPFD was $200 \pm 10 \mu \mathrm{mol} \mathrm{m} \mathrm{m}^{-2} \mathrm{~s}^{-1}$ and the photoperiod $16 \mathrm{~h}$. The initial value of air humidity was set at $98 \%$ and was decreased until the $\mathrm{RH}$ in the glass chamber attained the ambient value at the end of acclimatization. Temperature was kept at $25 \pm 2{ }^{\circ} \mathrm{C}$ during the light and $22 \pm 1{ }^{\circ} \mathrm{C}$ during the dark period.

The analyses were performed in leaves at time zero (day 0) of transfer to acclimatization, during the first seven days (day 1 to day 7) and at days 14 and 21 . Samples were collected in the middle of the light period.

Stomatal index, SI [\%], was calculated as SF/(SF+EF) $\times 100$ where SF and EF are number of stomata and number of epidermal cells, respectively, per unit leaf area of the first fully expanded leaf (Carvalho et al. 2002). To calculate trichome index, the number of trichomes (TF) replaces SF in the above formula.

The detection of ROS was carried out as described by Fryer et al. (2002). Leaves were detached and incubated in $5 \mathrm{mM} \mathrm{3,3}$ ' diaminobenzidine (DAB) at $\mathrm{pH} 3.8$ to detect $\mathrm{H}_{2} \mathrm{O}_{2}$ or in $6 \mathrm{mM}$ nitroblue tetrazolium (NBT) to detect $\mathrm{O}_{2}^{-}$.

Enzyme activities: The extracts for measuring enzyme activities were prepared at $4{ }^{\circ} \mathrm{C}$ from $0.5 \mathrm{~g}$ of frozen leaf tissue ground with $50 \%(\mathrm{~m} / \mathrm{m})$ polyvinylpolypyrrolidone (PVPP). The extraction buffer was $0.35 \mathrm{M}$ Tris- $\mathrm{HCl}$ (pH 8) supplemented with $20 \mathrm{mM}$ EDTA; $11 \mathrm{mM}$ sodium diethyldithiocarbamate (DETC), $15 \mathrm{mM}$ cystein (Jacobs et al. 1999), and $0.2 \mathrm{mM}$ phenylmethylsulfonyl fluoride (PMSF). Extracts were centrifuged at $27000 \mathrm{~g}$ for $10 \mathrm{~min}$ at $4{ }^{\circ} \mathrm{C}$ and the supernatants, desalted through PD-10 columns (GE Healthcare Lifesciences, Little Chalfont, UK), were used for all the determinations. Total protein was quantified by the method of Bradford (1976) using a commercial kit (Bio-Rad, Hercules, CA, USA).

Ascorbate peroxidase (APX; EC 1.11.1.11) activity was determined at $25{ }^{\circ} \mathrm{C}$ using a modification of the method of Hossain and Asada (1984). The reaction mixture of $1 \mathrm{~cm}^{3}$ contained $50 \mathrm{mM}$ potassium phosphate$\mathrm{KOH}, \mathrm{pH} 7.5,0.5 \mathrm{mM}$ AsA, $0.1 \mathrm{mM}$ EDTA and the enzyme sample ( $c a 14 \mu \mathrm{g}$ protein). The oxidation rate of AsA was estimated between 1.0 and $60 \mathrm{~s}$ after starting the reaction by adding $0.2 \mathrm{mM} \mathrm{H}_{2} \mathrm{O}_{2}$.

Dehydroascorbate reductase (DHAR; EC 1.8.5.1) activity was determined according to the method of Dalton et al. (1993) following the increase in absorbance $\left(\mathrm{A}_{265}\right)$ due to ascorbate formation (coefficient of absorbance $=14 \mathrm{mM}^{-1} \mathrm{~cm}^{-1}$ ). The assay mixture contained 0.1 M Hepes-KOH buffer pH 7.0, $2.5 \mathrm{mM}$ GSH, $0.5 \mathrm{mM}$ DAsA, $0.1 \mathrm{mM}$ EDTA and the enzyme sample ( $c a 35 \mu \mathrm{g}$ protein) in a final volume of $1 \mathrm{~cm}^{3}$. The reaction rate was corrected for the nonenzymatic reduction of DAsA by GSH. A factor of 0.98 to account for the small contribution to the absorbance by GSSG was also considered.

Monodehydroascorbate reductase (MDHAR; EC 1.6.5.4) activity was determinated by following the decreased in $\mathrm{A}_{340}$ due to NADH oxidation, as described by Arrigoni et al. (1981), in a coupled test system, in which the monodehydroascorbate radical is produced by ascorbate oxidase in Tris- $\mathrm{HCl}$ buffer, $\mathrm{pH} 7.5$, containing $0.2 \mathrm{mM}$ NADH, $2.5 \mathrm{mM}$ AsA, 0.5 units ascorbate oxidase (from Cucurbita species, Sigma-Aldrich) and enzyme extract ( $c a 14 \mu \mathrm{g}$ protein) in a final volume of $1 \mathrm{~cm}^{3}$ at $25^{\circ} \mathrm{C}$.

Glutathione reductase (GR; EC 1.6.4.2) was assayed by the decrease in $\mathrm{A}_{340}$ due to NADPH oxidation (coefficient of absorbance $=6.22 \mathrm{mM}^{-1} \mathrm{~cm}^{-1}$ ), as described by Schaedle and Bassham (1977), in a reaction

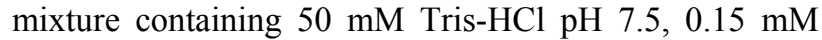
NADPH, $0.5 \mathrm{mM}$ GSSG, $3 \mathrm{mM} \mathrm{MgCl}_{2}$ and the sample (ca. $35 \mu \mathrm{g}$ protein).

Superoxide dismutase (SOD; EC 1.15.1.1) was assayed by the ferricytochrome $\mathrm{C}$ method using xanthine/xanthine oxidase as the source of superoxide radicals (McCord and Fridovich 1969) in a $1 \mathrm{~cm}^{3}$ reaction mixture containing $50 \mathrm{mM}$ potassium phosphate- $\mathrm{KOH}$ buffer $\mathrm{pH}$ 7.6, 0.1 mM EDTA, $0.01 \mathrm{mM}$ cytochrome $c$, $0.05 \mathrm{mM}$ xanthine, 0.03 units xanthine oxidase and the enzyme sample ( $\mathrm{ca} 14 \mu \mathrm{g}$ protein).

Catalase (CAT; EC 1.11.1.6) is directly determined by the decomposition of $\mathrm{H}_{2} \mathrm{O}_{2}$ at $240 \mathrm{~nm}$ in a $1 \mathrm{~cm}^{3}$ mixture containing $50 \mathrm{mM}$ potassium phosphate- $\mathrm{KOH}$ $\mathrm{pH} 7.0,10 \mathrm{mM} \mathrm{H}_{2} \mathrm{O}_{2}$ and the sample (ca $35 \mu \mathrm{g}$ protein).

Glutathione transferase (GT; EC 2.5.1.18) was assayed as the increased of $\mathrm{A}_{340}$ due to the conjugation of $\mathrm{GSH}$ to 1-chloro-2,4dinitrobenzene (CDNB), as described by Drotar et al. (1985), in $100 \mathrm{mM}$ potassium phosphate-KOH, pH 7.0, containing $2 \mathrm{mM} \mathrm{CDNB,} 2 \mathrm{mM}$ GSH and enzyme source (ca. 14 - $35 \mu \mathrm{g}$ protein). 
Reduction of $\mathrm{H}_{2} \mathrm{O}_{2}$ by peroxiredoxins (PRX) was quantified through a non-enzymatic, DTT-dependent activity assay by measuring the decrease in $\mathrm{H}_{2} \mathrm{O}_{2}$ concentration in the assay solution. The assay contained $100 \mathrm{mM}$ K-Pi buffer ( $\mathrm{pH} 7.0$ ), 0.3 to $3 \mu \mathrm{M}$ peroxiredoxin, $10 \mathrm{mM}$ DTT, and $100 \mu \mathrm{M} \mathrm{H}_{2} \mathrm{O}_{2}$. The reaction was initiated with $\mathrm{H}_{2} \mathrm{O}_{2}$ and stopped with trichloroacetic acid. After adding $10 \mathrm{mM} \mathrm{Fe}\left(\mathrm{NH}_{4}\right)_{2}\left(\mathrm{SO}_{4}\right)_{2}$ and $2.5 \mathrm{M}$ potassium thiocyanate (KSCN), the $A_{480}$ was measured to quantify the $\mathrm{H}_{2} \mathrm{O}_{2}$ contents of the solution, and $\mathrm{H}_{2} \mathrm{O}_{2}$ reduction rates were calculated.

Native PAGE and gel activity staining: Isoforms of CAT, SOD, APX, and GR were separated in nondenaturing polyacrylamide gels by the procedure of Laemmli (1970). Equal amounts of protein extracts $(25 \mu \mathrm{g})$ were loaded on $7 \%$ (CAT) or $10 \%$ (SOD, GR, and APX) polyacrylamide gels. For SOD, the gel was stained according to Rao et al. (1996). Gels were incubated for $30 \mathrm{~min}$ in $50 \mathrm{mM}$ potassium phosphate buffer ( $\mathrm{pH}$ 7.8) containing $1 \mathrm{mM}$ EDTA. To identify $\mathrm{KCN}$ and $\mathrm{H}_{2} \mathrm{O}_{2}$ sensitive isoforms, this incubation solution contained $3 \mathrm{mM} \mathrm{KCN}$ or $5 \mathrm{mM} \mathrm{H}_{2} \mathrm{O}_{2}$, respectively. This step was followed by incubation in $50 \mathrm{mM}$ potassium phosphate buffer $(\mathrm{pH} 7.8)$ containing $0.245 \mathrm{mM}$ nitroblue tetrazolium, $33.2 \mathrm{mM}$ riboflavin, and $0.2 \%$ tetramethylethylene diamine (TEMED) in darkness for $30 \mathrm{~min}$ before transfer to PPFD of $200 \mu \mathrm{mol} \mathrm{m} \mathrm{m}^{-2} \mathrm{~s}^{-1}$ to visualize SOD isoform bands (Donahue et al. 1997).

To visualize the CAT profile, gels were stained by the procedure of Anderson et al. (1995). The gels were incubated in $3.27 \mathrm{mM} \mathrm{H}_{2} \mathrm{O}_{2}$ for $25 \mathrm{~min}$, rinsed in distilled water, and then stained in a solution containing $1 \%(\mathrm{~m} / \mathrm{v})$ potassium ferricyanide and $1 \%(\mathrm{~m} / \mathrm{v})$ ferric chloride.

Isoforms of APX were visualized by incubating the gels for $30 \mathrm{~min}$ in $50 \mathrm{mM}$ potassium phosphate buffer (pH 7.0) containing $2 \mathrm{mM}$ ascorbate, followed by an incubation in the same buffer containing $4 \mathrm{mM}$ ascorbate and $2 \mathrm{mM} \mathrm{H}_{2} \mathrm{O}_{2}$ for $20 \mathrm{~min}$. Finally, gels were stained in $50 \mathrm{mM}$ potassium phosphate buffer $(\mathrm{pH}$ 7.8) containing $28 \mathrm{mM}$ TEMED and $2.45 \mathrm{mM}$ nitroblue tetrazolium for $15 \mathrm{~min}$.

GR was detected by incubating the gels for $60 \mathrm{~min}$ in the darkness in $50 \mathrm{mM}$ Tris- $\mathrm{HCl}$ buffer $(\mathrm{pH} 7.5)$ containing $0.5 \mathrm{mM}$ 3-(4,5-dimethylthiazol-2-4)-2,5diphenyl tetrazolium bromide, $0.7 \mathrm{mM}$ 2,6-dichlorophenolindophenol, $3.4 \mathrm{mM} \mathrm{GSSG}$, and $0.5 \mathrm{mM}$ NADPH. The staining reaction was stopped by adding $7.5 \%(\mathrm{v} / \mathrm{v})$ glacial acetic acid to the staining buffer.

Relative quantification of isoenzyme activities was determined using the software Quantity One (Bio-Rad, Hercules, CA, USA).

Peroxiredoxin immunoblotting: Polyclonal antibodies against cytosolic type II Prx C, chloroplast-located type II Prx E, chloroplast-located 2-cys Prx, chloroplast-located Prx Q and mitochondria-located type II Prx F, kindly given by Prof. K.-J. Dietz (Bielefeld University, GE, USA). Western blot analysis was performed by electrophoretic transfer of proteins, separated by SDSPAGE, to a nitrocellulose membrane (Millipore) and probed with the respective antibodies using the procedure described by Ferreira et al. (1996).

RNA isolation and real-time PCR: Total RNA from leaves was extracted by adapting the method described by Chang et al. (1993). $2 \%(\mathrm{~m} / \mathrm{v})$ cetyltrimethylammonium bromide (CTAB) was complemented with $2 \%$ PVPP $(\mathrm{m} / \mathrm{v}), 100 \mathrm{mM}$ Trizma-HCl, $25 \mathrm{mM} \mathrm{Na}{ }_{2}$ EDTA, and $2 \mathrm{M}$ $\mathrm{NaCl} ; \mathrm{pH} 8.0$ and the buffer was heated to $85^{\circ} \mathrm{C}$ prior to the addition of $400 \mathrm{~mm}^{3} \beta$-mercaptoethanol. Tissues were reduced to powder in liquid $\mathrm{N}_{2}$ and $20 \mathrm{~cm}^{3}$ extraction buffer were added. The same volume of chlorophorm + isoamyl alcohol (24:1) was then added. This step was followed by a centrifugation at $12000 \mathrm{~g}$ for $30 \mathrm{~min}$ at $20{ }^{\circ} \mathrm{C}$ and repeated once. The aqueous phase was transferred to a new tube, and a $10 \mathrm{M} \mathrm{LiCl} \mathrm{(v/v)} \mathrm{was}$ added. The sample was incubated at $0{ }^{\circ} \mathrm{C}$ overnight and then centrifuged at $12000 \mathrm{~g}$ for $20 \mathrm{~min}$ at $4{ }^{\circ} \mathrm{C}$. The pellet

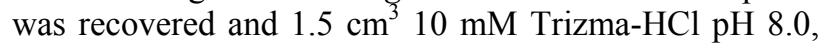
complemented with $1 \mathrm{mM} \mathrm{Na} \mathrm{N}_{2}$ EDTA, $1 \mathrm{M} \mathrm{NaCl}$ and $0.5 \% \operatorname{SDS}(\mathrm{m} / \mathrm{v})$, previously heated to $37^{\circ} \mathrm{C}$ was added. The same volume of chlorophorm + isoamyl alcohol (24:1) was added and this step was followed by a centrifugation at $12000 \mathrm{~g}$ for $10 \mathrm{~min}$ at $20{ }^{\circ} \mathrm{C}$ and repeated once. Ethanol $100 \%$ (2.5 volumes) was added and the samples were incubated for $1 \mathrm{~h}$ at $-80^{\circ} \mathrm{C}$ and then washed with ethanol $70 \%$. After drying, the RNA was resuspended in the desired volume of distilled water. RNA samples were treated with $R Q 1$ RNase-free DNase (Promega, Madison, WI, USA) and reverse transcribed using random hexamers and Superscript II RNase Hreverse transcriptase (Invitrogen, Carlsbad, CA, USA) according to the manufacturer's recommendations.

Primer pairs used for amplification of all the genes studied are presented in Table 1 . The genomic sequences for plantain available in the GeneBank database were retrieved and the program Beacon Designer 6 (Premier Biosoft) was used to design the primers pairs. Real-time RT-PCR reactions contained $20 \mathrm{~mm}^{3}$ reaction mixture composed of cDNA, $0.5 \mu \mathrm{M}$ gene-specific primers and master mix $i Q S Y B R$ Green Supermix (Bio-Rad) using an $i Q 5$ real time PCR (Bio-Rad). Amplification of PCR products was monitored via intercalation of SYBR-Green (included in the master mix). The following program was applied: initial polymerase activation, $95^{\circ} \mathrm{C}, 3 \mathrm{~min}$; then 40 cycles at $95{ }^{\circ} \mathrm{C} 15 \mathrm{~s}$ (denaturation), $57{ }^{\circ} \mathrm{C} 30 \mathrm{~s}$ (annealing), $72{ }^{\circ} \mathrm{C} \quad 30 \mathrm{~s}$ (extension) with a single fluorescence reading taken at the end of each cycle. Each run was completed with a melting curve analysis to confirm the specificity of amplification and confirm the lack of primer dimers. Further, RT-PCR products were resolved on $2 \%(\mathrm{~m} / \mathrm{v})$ agarose gels and run at $4 \mathrm{~V} \mathrm{~cm}^{-1}$ in Tris-acetate-EDTA buffer (TAE) with a 50-bp DNAstandard ladder (Invitrogen) to confirm the existence of a single product of the desired length.

To generate a baseline-subtracted plot of the logarithmic increase in fluorescence signal $(\Delta \mathrm{Rn})$ versus 
cycle number, baseline data were collected between the cycles 10 and 27. All amplification plots were analysed with an $R_{n}$ threshold of 0.2 to obtain $\mathrm{C}_{\mathrm{T}}$ (threshold cycle) and the data obtained were exported into a MS Excel. In order to compare data from different PCR runs or cDNA samples, $\mathrm{C}_{\mathrm{T}}$ values were normalized to the $\mathrm{C}_{\mathrm{T}}$ value of Act2, a housekeeping gene expressed at a relatively high and constant level. Gene expression was normalized to that of Act2 by subtracting the $\mathrm{C}_{\mathrm{T}}$ value of Act2 from the $\mathrm{C}_{\mathrm{T}}$ value of the gene of interest.

Statistical analysis: All experiments were performed three times with 3 repetitions. Statistical analyses were carried out using SPSS version 12. All situations were analyzed using non-parametric analysis (Kruskall-Wallis or Mann-Whitney), both at $5 \%$ significance level.

Table 1. Real-time PCR primers used for evaluation of mRNA levels of the enzymes studied. Accession numbers correspond to sequences available in the GeneBank database (http://www.ncbi.nlm.nih.gov/sites/entrez) and in the Global Musa Genomics Consortium database (http://www.musagenomics.org/).

\begin{tabular}{|c|c|c|c|}
\hline Protein & Accession No. & Primer name & Primer sequence \\
\hline Actin & EF672732.1 & Ma-actin & $\begin{array}{l}\text { 5'-TTGATTCTGGTGATGGTGTGAGCC-3' } \\
\text { 3'-CTACCACTGCTGAACGGGAAATTG-5' }\end{array}$ \\
\hline MnSOD & AF510071.1 & Ma-MSOD & $\begin{array}{l}\text { 5'-ACGTCACCAACTACAACAATGCC-3' } \\
\text { 3'-GCCCAACCAAGTGTGCTGTG-5' }\end{array}$ \\
\hline $\mathrm{Cu}-\mathrm{ZnSOD}$ & DQ866814 & Ma-CZSOD & $\begin{array}{l}\text { 5'-TGGCAACGGGAGGCAATCTG-3' } \\
\text { 3'-AGGAGAGAATGAGGGAGGAGAGG-5' }\end{array}$ \\
\hline CAT & EU139298.1 & Ma-CAT & $\begin{array}{l}\text { 5'-CGCTCACCACAACAATCACTACG-3' } \\
\text { 3'-AATCACATTCTTCTCACGCTTGCC-5' }\end{array}$ \\
\hline APX & AF146521 & Ma-APX & $\begin{array}{l}\text { 5'-GTTCGGACCACCTCAGGGATG-3' } \\
\text { 3'-TCGTCTTTCTCGCTGCTCAGG-5' }\end{array}$ \\
\hline
\end{tabular}

\section{Results}

The histological analyses of plantain stomatal guard cells stained with NBT or DAB evidenced brown polymerization products, resulting from $D A B$ reacting with $\mathrm{H}_{2} \mathrm{O}_{2}$ in the presence of peroxidases and purple formazan deposits, which result from the reaction of NBT with $\mathrm{O}_{2}{ }^{-}$ (Fig. 1). The stomatal index and staining pattern was analysed in the adaxial and abaxial side of the leaves (Fig. 2A,B). The adaxial side showed the highest stomatal index in in vitro GM propagated plantlets, however, at the end of acclimatization the difference between treatments was not observed. No marked changes were observed in stomatal index on the abaxial side. The staining pattern was mostly similar in GM and TIB propagated plantlets with the exception of high staining percentage in guard cell on the abaxial side of in vitro GM plantlets.

The activities of the ascorbate-glutathione cycle enzymes APX, DHAR, MDHAR and GR were higher in

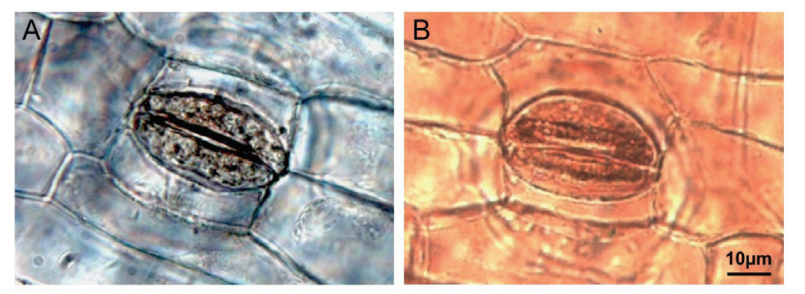

Fig. 1. Imaging of ROS accumulation in stomatal cells of plantain plantlets stained with NBT for superoxide radical $(A)$ and with $\mathrm{DAB}$ for hydrogen peroxide $(B)$.
GM plantlets on day 0 while TIB plantlets evidenced higher SOD, CAT, PRX and GT activities (Fig. 3). With the exception of GR and PRX, all the enzymes studied reached their maximum activity between days 3 and 5 in GM propagated plantlets, decreasing to minimum values on day 7. Conversely, in TIB plantlets only GR and APX activities increased in the first $3 \mathrm{~d}$. On day 21, GT, SOD, CAT and MDHAR stabilized at low activities in plantlets grown under both treatments. Two exceptions were APX and DHAR, showing rather high activity in GM and TIB, respectively.

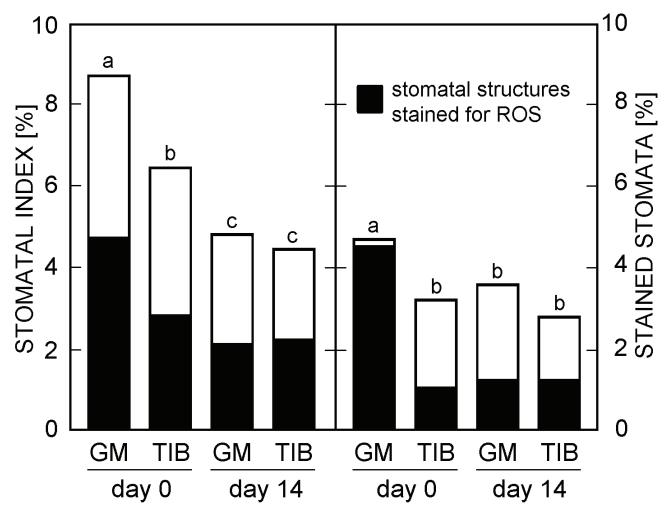

Fig. 2. Stomatal index and percentage of stained stomata in the adaxial (on the left) and abaxial (on the right) side of the leaves prior to transfer to ex vitro (day 0) and after acclimatization (day 14). Values indicated by different letters are significantly different at $5 \%$ using C-Dunnett multiple range test $(n=9)$. 
Two SOD isoenzymes, SOD A and SOD B, were detected upon treatment with $\mathrm{KCN}$ and $\mathrm{H}_{2} \mathrm{O}_{2}$, confirming that they are $\mathrm{Mn}$ isoforms. Both were present at higher levels in GM than in TIB on day 0, decreasing slightly with time. CAT showed one isoenzyme with higher activity in TIB, and it was unaltered with time. It was possible to detect two isoenzymes of APX; APX-A, whose activity decreased with time while the activity of APX-B increased slightly in both treatments. The two GR isoenzymes detected showed the highest activity in GM on day 0 (Table 2).
Western blot analysis of five peroxiredoxins allowed the characterization of the response in different cell compartments (Fig. 4). From three PRX in chloroplasts Type II E was the most abundant in both treatments with maximum on day 7. Also, PRX Q showed maximum values on day 7 in both treatments while 2-cys PRX was hardly detected in GM grown plantlets and showed the highest quantity on day 7 in TIB. Cytosol located type II PRX C was hardly detected during acclimatization. In fact, in GM grown plantlets this PRX was not even

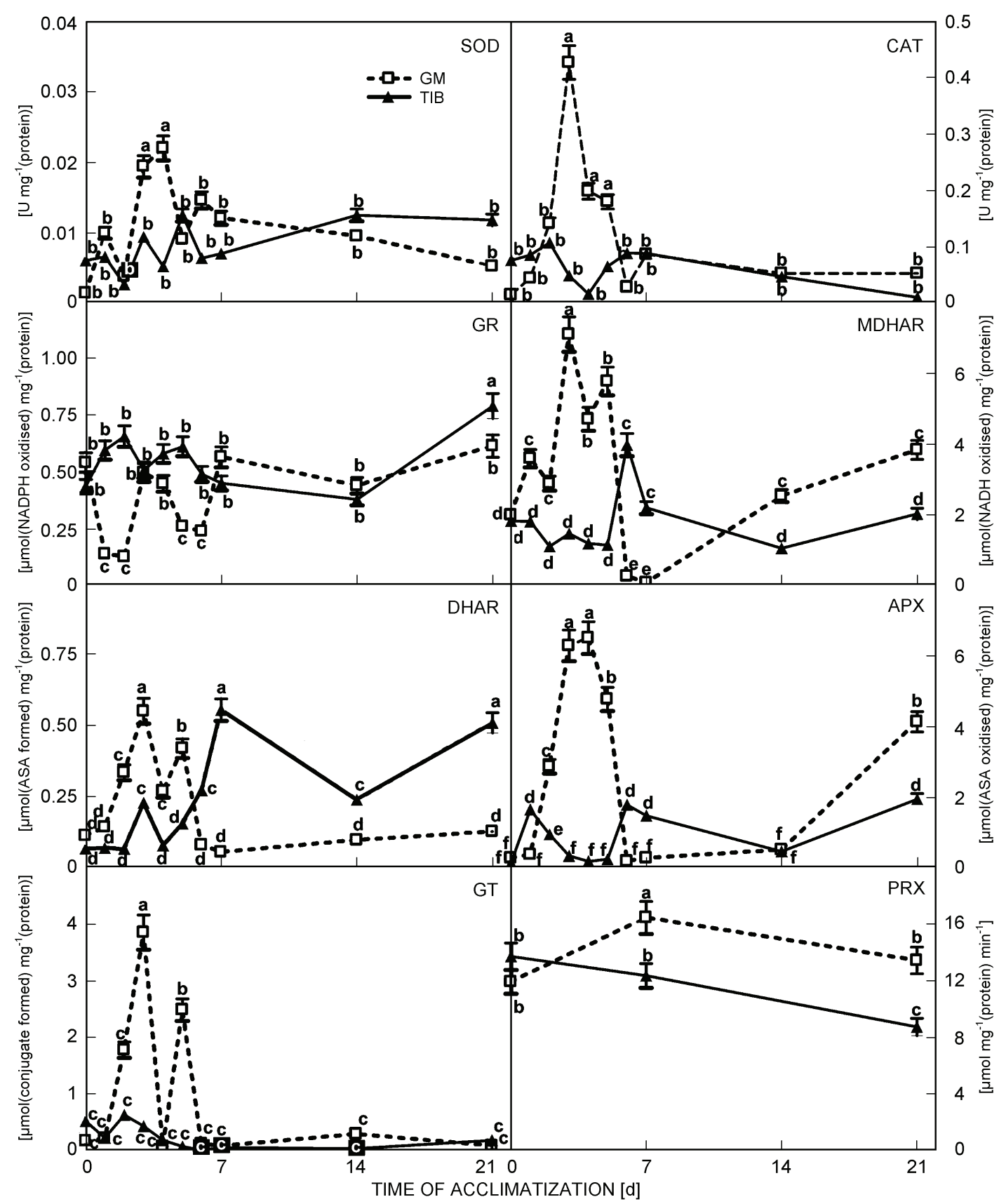

Fig. 3. Total soluble enzyme activities in leaves of plantain plantlets propagated under both systems (GM and TIB). Different letters are used when values differ significantly $(P<0.05$; Mann-Whitney test, $n=9)$. 
Table 2. Activities of SOD, CAT, APX and GR isoenzymes in leaves of acclimatizing plantain plantlets propagated under GM and TIB were quantified in relation to the value for GM at day 0 (100\% activity). Total protein extracts were subjected to native PAGE followed by activity staining for the four enzymes. Discrimination between SOD isoforms was revealed by inhibition with $\mathrm{H}_{2} \mathrm{O}_{2}$ and $\mathrm{KCN}$.

\begin{tabular}{llrrrrr}
\hline & GM & \multicolumn{5}{c}{ TIB } \\
& 0 & 7 & 21 & 0 & \multicolumn{1}{c}{7} & \multicolumn{1}{c}{21} \\
\hline SOD-A & 100 & 98 & 96 & 94 & 93 & 94 \\
SOD-B & 100 & 77 & 75 & 72 & 71 & 70 \\
CAT & 100 & 108 & 102 & 116 & 116 & 117 \\
APX-A & 100 & 93 & 96 & 94 & 92 & 89 \\
APX-B & 100 & 87 & 103 & 98 & 105 & 109 \\
GR-A & 100 & 97 & 87 & 84 & 83 & 78 \\
GR-B & 100 & 96 & 89 & 87 & 85 & 81 \\
\hline
\end{tabular}

detected on day 0. Conversely, type II PRX F, located in mitochondria was very abundant in both treatments from day 0 until the end of acclimatization.

The expression of key genes of the anti-oxidative defence system was monitored using real time RT-PCR (Fig. 5). The expression of all genes was higher in GM plantlets all along the experiment with the exception of CuZnSOD which only increased significantly on day 21 . $C A T$ and $M n S O D$ showed peaks of expression on day 3 while the expression of $A P X$ was constantly high. In TIB plantlets, both $A P X$ and $M n S O D$ showed the lowest values on day 7 .

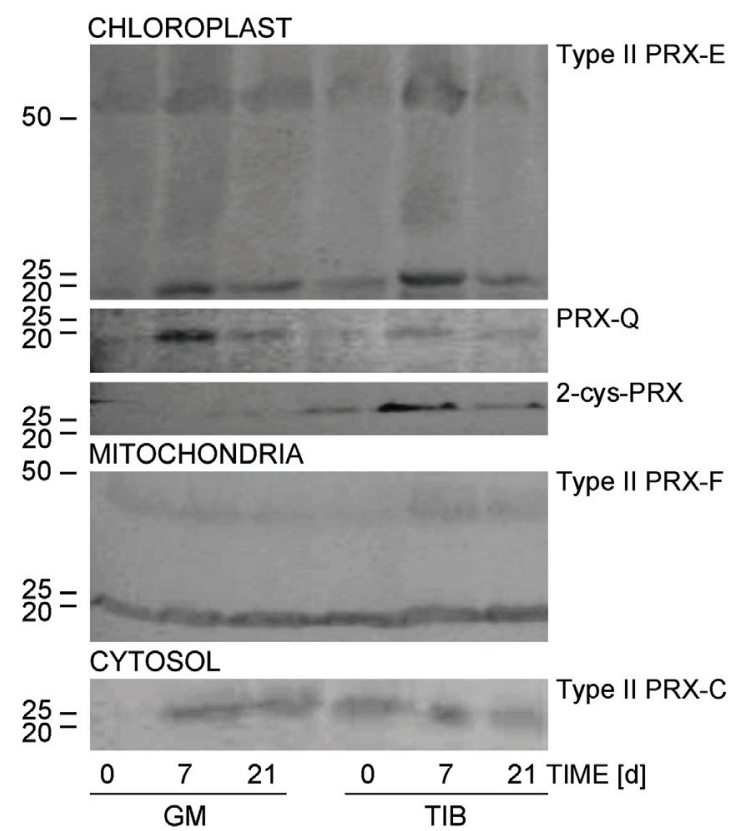

Fig. 4. Western blots of five different peroxiredoxins localized in three cellular compartments: chloroplast (2-cys Prx; type II Prx E; Prx Q), mitochondria (type II Prx F) and cytosol (type II Prx C). Protein samples were subjected to SDS-page, transferred to a nitro-cellulose membrane and probed with the specific antibodies. Western blots were performed in leaves of plantain plantlets propagated under both systems (GM and TIB) on day 0 of transfer to acclimatization and after 7 and $21 \mathrm{~d}$ of ex vitro growth.

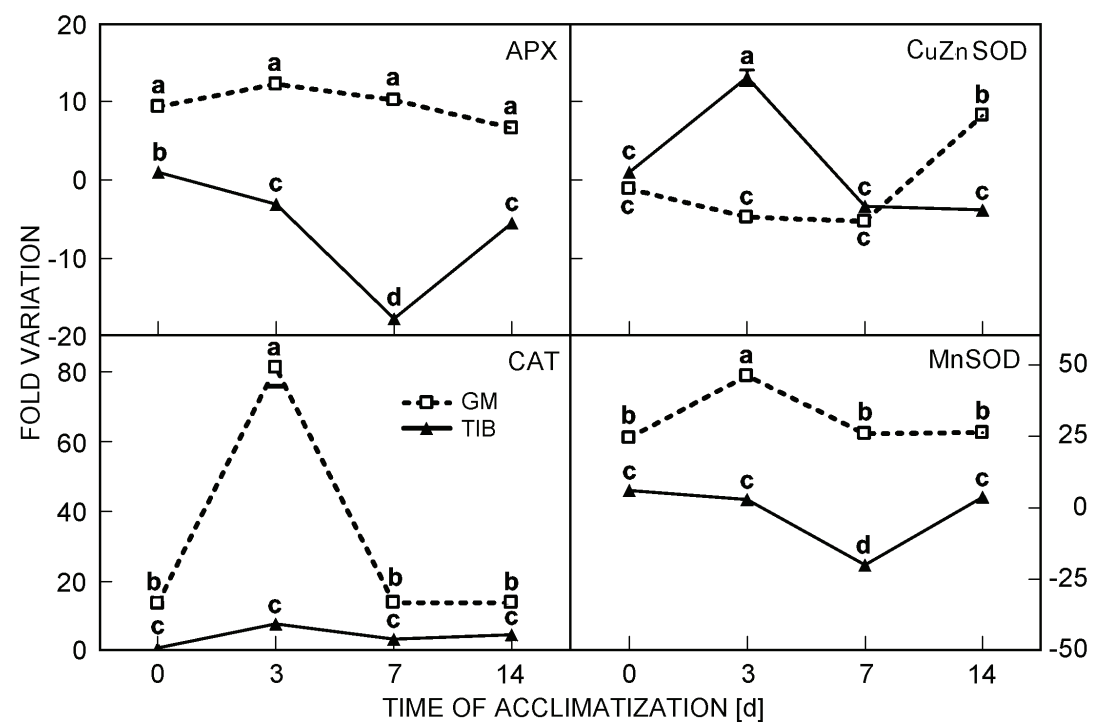

Fig. 5. Expression levels of genes of the anti-oxidative system. Quantification of mRNA levels was performed on day 0 of each propagation method and after 3, 7 and $14 \mathrm{~d}$ of ex vitro growth. mRNA was isolated from leaves, converted to cDNA, and subjected to real-time PCR. Relative amounts were calculated and normalized with respect to plantain Act 2 mRNA. Each time point in each propagation method (GM and TIB) is compared to day 0 leaves propagated in GM (control, day 0 = zero fold change). For clarity purposes, different scales were used. Values indicated by different letters are significantly different at $5 \%$ by C-Dunnett multiple range test. 


\section{Discussion}

Plantain plantlets propagated in TIB had a better capacity to sustain the stress imposed upon transfer to ex vitro conditions (Aragon et al. 2005). The present work aims to get an insight into the cellular features that support the quality of TIB plantlets at the level of anti-oxidative stress response. For that purpose in situ ROS deposition, the activity of anti-oxidative stress enzymes and the expression of the correspondent genes were compared in ex vitro plantain plantlets propagated in vitro through GM and TIB.

DAB staining of the stomatal guard cells revealed the deposition of $\mathrm{H}_{2} \mathrm{O}_{2}$ associated with organelles engaged in electron transport (Desikan et al. 2004, Kwak et al. 2006, Vilela et al. 2007). The similar distribution of stomata staining pattern of in vitro TIB plantlets as compared to those $14 \mathrm{~d}$ after transfer to ex vitro conditions demonstrated that plantain grown in this system developed leaves morphologically close to autotrophic leaves formed ex vitro.

Most plants display an efficient defence system able to scavenge ROS, keeping their concentration at levels adjusted to cellular signaling (Mullineaux et al. 2006, Ślesak et al. 2007). SOD, CAT and the ascorbateglutathione cycle enzymes are the key players of that defence system (Bat'ková et al. 2008). It was possible to identify specific characteristics of the anti-oxidant efficiency in GM and TIB plantlets during ex vitro growth. The primary response to oxidative stress is provided by $\mathrm{SOD}$, the enzyme that scavenges $\mathrm{O}_{2}^{-}$into $\mathrm{H}_{2} \mathrm{O}_{2}$ (Alscher et al. 2002, Shao et al. 2008), which was transiently activated in GM plantlets. During the first week ex vitro two features were observed in GM plantlets: the increased activity of ascorbate-glutathione cycle enzymes APX, DHAR and MDHAR, and the activation of PRXs, acting against a broader spectrum of peroxides than APX (Dietz 2003). We can infer that these plantlets were subjected to higher levels of stress, and this response must be related to the elimination of excess $\mathrm{H}_{2} \mathrm{O}_{2}$, to be kept at levels adjusted for signalling. The high activity of GT during the first week can help repair cell structures damaged by ROS (Wangwattana et al. 2008). As a whole, the up-regulation of the anti-oxidant system during the first $7 \mathrm{~d}$ after ex vitro transfer suggest that GM plantlets are less suited to cope with the stress at the moment of transfer than TIB plantlets. However, at

\section{References}

Alscher, R., Erturk, N., Heath, L.: Role of superoxide dismutases (SODs) in controlling oxidative stress in plantlets. - J. exp. Bot. 372: 1331-1341, 2002.

Anderson, M., Prasad, T., Stewart, C.: Changes in isozyme profiles of catalase, peroxidase and glutathione reductase during acclimation to chilling in mesocotyls of maize seedlings. - Plant Physiol. 109: 1247-1257, 1995.

Aragón, C.E., Escalona, M., Capote, I., Pina, D., Cejas, I., Rodríguez, R., Cañal, M.J., Sandoval, J., Roels, S., the end of acclimatization antioxidant system in GM and TIB plantlets behaved similarly.

Transcript levels of $M n S O D, A P X$ and $C A T$ showed a stronger up-regulation in GM than in TIB plantlets. Two $\mathrm{Mn}$ isoforms of SOD were identified while three MnSODs were described in Lycopersicon esculentum propagated under GM. In Nicotiana benthamiana (Carvalho et al. 2008) and Vitis vinifera (Carvalho et al. 2006) also FeSODs were observed. Although total CAT activity was low under both propagation techniques, one isoform with rather high activity was observed, as in $L$. esculentum and $V$. vinifera, while $N$. benthamiana displayed two isoforms (Carvalho et al. 2006, 2008). APX revealed two isoforms, while in L. esculentum and $V$. vinifera three isoforms were detected (Carvalho et al. 2006, 2008). The heterogeneity of the isoenzyme set present in each plant species, influences the effectiveness of the response mechanism to the damage caused by the excess of ROS, due to different substrate affinities and cellular localizations.

Immunoblotting of PRXs revealed specific band patterns. Chloroplast isoforms, more abundant in TIB plantlets, could play the lead role in the better adjustment of these plantlets, e.g. 2-Cys-PRX might early eliminate $\mathrm{H}_{2} \mathrm{O}_{2}$ (Konig et al. 2002). The polymerization strategy of Type II PRX-E on day 7 is a response to stress conditions (Konig et al. 2002). Mitochondria Type II PRX-F showed similar patterns under both propagation techniques, confirming that the major differences in PRX metabolism occur in the chloroplasts. The cytosol PRX II-C was present in TIB plantlets from day 0 while in GM it was only detected after some days after ex vitro transfer. This again suggests that TIB plantlets are better prepared to withstand ex vitro conditions. A. thaliana revealed very low levels of PRX II-C mRNA under optimal conditions, but increased under high irradiance or salinity stress (Dietz 2003).

In vitro propagated banana and plantain have been described as displaying a good anti-oxidant capacity (Mokbel and Hashinaga 2005). The present study elucidates the mechanisms by which TIB grown plantlets are able to better sustain and overcome oxidative stress than GM grown plantlets, thus enhancing their propagation capacity and improving their growth.
Debergh, P., González-Olmedo, J.L.: Photosynthesis and carbon metabolism in plantain (Musa AAB) growing in temporary immersion bioreactor (TIB) and $e x$ vitro acclimatization. - In vitro cell. dev. Biol. Plant. 41: 550-554, 2005.

Arrigoni, O., Dipierro, S.E., Borraccino, G.: Ascorbate free radical reductase: a key enzyme of the ascorbic acid system. - FEBS Lett. 125: 242-244, 1981.

Bat'ková, P., Pospíšilová, J., Synková, H.: Production of 
reactive oxygen species and development of antioxidative systems during in vitro growth and ex vitro transfer. - Biol. Plant. 52: 413-422, 2008.

Bradford, M.M.: A rapid and sensitive method for the quantification of microgram quantities of protein utilizing the principle of protein dye binding. - Anal. Biochem. 72: 248-254, 1976

Carvalho, L.C., Osório, M.L., Chaves, M.M., Amâncio, S.: Chlorophyll fluorescence as an indicator of photosynthetic competence of in vitro grapevine and chestnut under acclimatization. - Plant Cell Tissue Org. Cult. 67: 271-280, 2001.

Carvalho, L.C., Santos, P., Amâncio, S.: Effects of light intensity and $\mathrm{CO}_{2}$ concentration on growth and the acquisition of in vivo characteristics during acclimatization of grapevine regenerated in vitro. - Vitis 41: 1-6, 2002.

Carvalho, L.C., Santos, S., Vilela, B.J., Amâncio, S.: Solanum lycopersicon Mill. and Nicotiana benthamiana L. under high light show distinct responses to anti-oxidative stress. J. Plant Physiol. 165: 1300-1312, 2008.

Carvalho, L.C., Vilela, B.J., Vidigal, P., Mullineaux, P.M., Amâncio, S.: Activation of the ascorbate-glutathione cycles is an early response of micropropagated Vitis vinifera L. explants transferred to ex vitro. - Int. J. Plant Sci. 167: 759770, 2006.

Chang, S., Puryear, J., Cairney, J.: A simple and efficient method for isolating RNA from pine trees. - Plant mol. Biol. Rep. 11: 113-116, 1993.

Dalton, D., Baird, L., Langeberg, L., Taughet, C., Anyan, W., Vance, C., Sarath, G.: Subcellular localization of oxygen defence 21 enzymes in soybean (Glycine max L. Merr.) root nodules. - Plant Physiol. 102: 481-489, 1993.

Desikan, R., Cheung, M., Bright, J., Henson, D., Hancock, J., Neill, S.: ABA, hydrogen peroxide and nitric oxide signalling in stomatal guard cells. - J. exp. Bot. 55: 205-212, 2004.

Dietz, K.J.: Plant peroxiredoxins. - Annu. Rev. Plant Biol. 54: 93-107, 2003

Donahue, J., Okpodu, C., Cramer, C., Grabau, E., Alscher, R.: Responses of antioxidants to paraquat in pea leaves: relationships to resistance. - Plant Physiol. 113: 249-257, 1997.

Drotar, A., Phelps, P., Fall, R.: Evidence for glutathione peroxidase activities in cultured plant cells. - Plant Sci. 42: 35-40, 1985.

Escalona, M., Samson, G., Borroto, C., Desjardins, Y.: Physiology of the effects of temporary immersion bioreactors on micropropagated pineapple plantlets. - In Vitro cell. dev. Biol. Plant. 39: 651-656, 2003.

Ferreira, R., Franco, E., Teixeira, A.: Covalent dimerization of ribulosebisfosphate carboxylase subunits by UV radiation. Biochem. J. 318: 227-234, 1996.

Fryer, M., Oxborough, K., Mullineaux, P., Baker, N.: Imaging of photoxidative stress responses in leaves. - J. exp. Bot. 53: 1249-1254, 2002.

Hossain, M., Asada, A.: Inactivation of ascorbate peroxidase in spinach chloroplasts on dark addition of hydrogen peroxide: its protection by ascorbate. - Plant Cell Physiol. 25: 12851295, 1984.

Jackson, M., Abbott, A., Belcher, A., Hall, K., Butler, R., Cameron, J.: Ventilation in plant tissue cultures and effects of poor aeration on ethylene and carbon dioxide accumulation, oxygen depletion and explant development. Ann. Bot. 67: 229-237, 1991.

Jacobs, A., Dry, I., Robinson, S.: Induction of different pathogenesis-related cDNAs in grapevine infected with powdery mildew and treated with ethephon. - Plant Pathol. 48: 325-336, 1999.

Kitto, S.L.: Commercial micropropagation. - HortScience 32: 1012-1014, 1997.

König, J., Baier, M., Horling, F., Kahmann, U., Harris, G., Schürmann, P., Dietz, K.-J.: The plant-specific function of 2-cys-peroxiredoxin-mediated detoxification of peroxides in the redox-hierarchy of photosynthetic electron flux. - PNAS 99: 5738-5743, 2002.

Kwak, J.M., Nguyen, V., Schroeder, J.I.: The role of reactive oxygen species in hormonal responses. - Plant Physiol. 141: 323-329, 2006.

Laemmli, U.K.: Cleavage of structural proteins during the assembly of the head of bacteriophage T4. - Nature 227: 680-685, 1970.

Lorenzo, J., Blanco, M., Peláez, O., González, A., Cid, M., Iglesias, A., González, B., Escalona, M., Espinosa, P., Borroto, C.: Sugarcane micropropagation and phenolic excretion. - Plant Cell Tissue Organ Cult. 65: 1-8, 2001.

McCord, J., Fridovich, I.: Superoxide dismutase: an enzymic function for erythrocuprein. - J. Inorg. Biochem. 244: 60496055, 1969.

Mokbel, M.S., Hashinaga, F.: Antibacterial and antioxidant activities of banana (Musa, AAA cv. Cavendish) fruit peels. - Amer. J. Biochem. Biotechnol. 1: 126-132, 2005.

Mullineaux, P.M., Karpinski, S., Baker, N.: Spatial dependence for hydrogen peroxide-directed signalling in light stressed plants. - Plant Physiol. 141: 346-350, 2006.

Murashige, T., Skoog, F.: A revised medium for rapid growth and bioassays with tobacco tissue cultures. - Physiol. Plant. 15: 473-497, 1962.

Rao, M.V., Paliyath, G., Ormrod, D.P.: Ultraviolet-B- and ozone-induced biochemical changes in antioxidant enzymes of Arabidopsis thaliana. - Plant Physiol. 110: 125-136, 1996.

Schaedle, M., Bassham, J.: Chloroplast glutathione reductase. Plant Physiol. 59: 1011-1012, 1977.

Shao, H., Chu, L., Lu, Z., Kang, C.: Primary antioxidant free radical scavenging and redox signaling pathways in higher plant cells. - Int. J. biol. Sci. 4: 8-14, 2008.

Ślesak, I., Libik, M., Karpinska, B., Karpinski, S., Miszalski, Z.: The role of hydrogen peroxide in regulation of plant metabolism and cellular signalling in response to environmental stresses. - Acta Biochim. Pol. 54: 39-50, 2007.

Tanaka, Y., Sano, T., Tamaoki, M., Nakajima, N., Kondo, N., Hasezawa, S.: Ethylene inhibits abscisic acid-induced stomatal closure in Arabidopsis. - Plant Physiol. 138: 23372343, 2005

Van Huylenbroeck, J.M., Piqueras, A., Deberg, P.C.: The evolution of photosynthetic capacity and the antioxidant enzymatic system during acclimatization of micropropagated Calathea plants. - Plant Sci. 135: 59-66, 2000.

Vilela, J., Carvalho, L.C., Ferreira, J., Amâncio, S.: Gain of function of stomatal movements in rooting Vitis vinifera $\mathrm{L}$. plantlets: regulation by $\mathrm{H}_{2} \mathrm{O}_{2}$ is independent of $\mathrm{ABA}$ before the protruding of roots. - Plant Cell Rep. 26: 2149-2157, 2007.

Wangwattana, B., Koyama, Y., Nishiyama, Y., Kitayama, M.: Characterization of PAP1-upregulated glutathione Stransferase genes in Arabidopsis thaliana. - Plant Biotechnol. 25: 191-196, 2008. 